\title{
THE EFFECT OF LABOUR LEGISLATION IN THE PROMOTION AND INTEGRATION OF PERSONS WITH DISABILITIES IN THE LABOUR MARKET
}

\author{
Elsabé Cynthia-Leigh Cole \\ BSocSc MA(Clinical Psychology) \\ Labour Law Consultant \\ Adriaan van der Walt \\ BJuris BA(Hons) LLB \\ Professor of Law, Faculty of Law \\ Nelson Mandela Metropolitan University \\ Port Elizabeth
}

\section{SUMMARY}

An absence of adequate legislation in South Africa resulted in inequality in the workplace and in society in general. The new constitutional democracy with a Bill of Rights intended to address this by promulgated legislation, and today the South African Constitutional and legislative provisions promoting equality are viewed as amongst the most progressive in the world. In regard to persons with disabilities, this progressive legislation, aimed to protect against discrimination, still seems to fail the very people it intended to promote and protect.

The legislation created awareness of the need for equality and the right of workers to employment and to decent working conditions. The right to equality is accorded to everybody through the Constitution of South Africa. The Bill of Rights is based on the notion of equality before the law, and the prohibition of discrimination on various grounds.

Despite this, the perception exists that persons with disabilities as a minority group are still being marginalized and are restricted in their right to exercise the right to participate and make a meaningful contribution to the labour market. This not only seems to be in contradiction with the constitutional right to choose an occupation, but has wider social and economic consequences. The ethos of equality legislation is to ensure that the workplace is representative of the society we live in. It is understandable that labour as a social phenomenon is not only concerned with workplace-related issues but with aspects encompassing the whole of the sociopolitical and economic scene.

South African labour legislation promulgated over the last two decades strives to align with the conventions and recommendations of the International Labour Organisations and in terms of the obligations of South Africa as a member state. 
However, the question prevails: is the legislation adequate to address the discrimination and inequality experienced by persons with disability? If so, why do statistics indicate such high unemployment amongst this group? Yet, there is a growing awareness that persons with disabilities represent enormous untapped economic potential.

According to the ILO report on The Right to Decent Work of Persons with Disabilities (1997), much has been accomplished in the international arena in recent years to improve the lives of disabled persons in the workplace.

This article will attempt to evaluate the efficacy of South African legislation in the promotion and integration of persons with disabilities in the labour market.

\section{GENERAL OVERVIEW AND BACKGROUND}

"O wonder! How many goodly creatures are there here! How beauteous mankind is! O brave new world that has such people in't!"1

Inequality and discrimination in the broader society and in the workplace are some of the key elements of the legacy of apartheid in South Africa. In the past persons with disabilities were excluded from mainstream society and experienced difficulties in accessing fundamental rights. ${ }^{2}$ Considering the history of South African labour relations, it is understandable that labour as a social phenomenon is not only concerned with workplace-related issues but also with aspects encompassing the whole of the socio-political and economic scene. This involvement is manifest in the approach to labour legislation in South-Africa in the post-apartheid era and the processes through which the current legislation came about. Current labour legislation seen against the preceding processes paints a picture of issues that beg redress.

Undoubtedly by discrimination stifles opportunities, wastes human talent needed for economic progress, and accentuates social tensions and inequalities. Combating discrimination forms an essential part for a long successful strategy to promote opportunities and a fair equitable workplace that is representative of the society we live in.

Under the new democracy and in support of the Constitution ${ }^{4}$ the South African Government promulgated the Employment Equity Act (hereinafter "EEA"), ${ }^{5}$ a progressive piece of legislation and policy interventions to give effect to section $9(3)$ of the Constitution that guarantees the fundamental right to equality.

In an attempt to protect the rights of persons with disabilities it is further supported by the Code of Good Practice on key aspects on employment of people with disabilities ${ }^{6}$ (hereinafter "Code of Good Practice") and the

Shakespeare quoted by Sir lan McKellen at the opening of the Paralympics London 2012.

Technical Assistance Guidelines on the Employment of People with Disabilities. Published by Department of Labour 2002. Foreword M M S Mdladlana, Minister of Labour.

3 Dupper, Garbers, Landman, Christianson, Basson and Strydom Essential Employment Discrimination Law (2004) 15-16.

The Constitution of the Republic of South Africa, Act 108 of 1996.

5 Employment Equity Act of 55 of 1998.

6 GN 1064 in GG 23718 of 19 August 2002. 
Technical Assistance Guidelines (hereinafter "TAG") that aim to promote equal opportunities and fair treatment in employment.

But questions remain: Does this progressive legislation and relevant codes and guidelines make a significant contribution to affirm persons with disabilities in the labour market? Does it offer sufficient protection from discrimination or make a meaningful contribution to providing for equal opportunities in the workplace?

\section{Problem formulation}

South African equality-labour legislation is viewed as amongst the most progressive in the world. Specific emphasis is placed on ensuring equality, the right to protection and benefit before the law, inter alia, for persons with disabilities.

The high level of unemployment amongst this designated group, in all categories of work, suggests that employers still have reservations in employing persons with disabilities. Statistics confirm that, although some progress has been made in the Government sector in terms of representation, very little representation has been achieved in the private sector.

The South African Government via President Zuma in the state of the nation address on 10 February 2011, declared the year of 2011 as the "year of job creation through meaningful economic transformation and inclusive growth". ${ }^{7}$ The State further embarked on a so-called new "growth path aimed to create five million jobs by 2020 and to bring down the unemployment statistics to 15 per cent. ${ }^{8}$

The South African Minister of Finance, Pravin Gordhan, suggested that South Africa may have to relax its labour laws to grow jobs to achieve this growth. ${ }^{9}$

Human beings strive for a better quality of life - alike to persons with disabilities. Employment provides not only a source of income but contributes to the improvement of quality of life of every individual in society. Victor Frankl so aptly described the meaning of work as a manner in which to improve mental health and providing sense to our existence.

The democratization of South Africa has ushered in a progressive democratic awareness of the needs and rights of previously disadvantaged groups, such as persons with disabilities.

\footnotetext{
Http://www.info.gov.za/speech/DynamicAction?pageid=461\&tid=27985 (accessed 2013-01 03).

$8 \mathrm{Http}: / /$ www.southafrica.info/abo ut/government/statenation2011a.htm (accessed 2013-0103).

$9 \quad \mathrm{Http} . / /$ www.southafrica.info/news/business/218099.htm (accessed 2012-12-27).

10 Moller Persoonlikheidsielkunde (1987) 12. Volgens Frankl, in die betekenis van werk, "word geestesgesondheid bevorder deur lewenstake op 'n sinvolle intensionele wyse aan te pak. Selfs die eenvoudigste taak moet die mens met oorgawe verrig. Die mens moet as't ware opgaan in sy taak ..."
} 
Although national legislation is in place to give effect to the Constitution, the efficacy, application and implementation of this legislation is at times questionable. According to the ILO report on The Right to Decent Work of Persons with Disabilities, ${ }^{11}$ launched by the ILO on the International Day of Disabled People, 3 December 2007, much has been accomplished in the international arena in recent years to improve the working lives of persons with disabilities.

Contrary to this picture, the majority of persons with disabilities in South Africa still continue to suffer restrictions of their rights. In the world of work, they tend to experience high unemployment, underemployment, have lower earnings and as a result of social and economic pressures often are forced to drop out of the labour market. Unfair discrimination against persons with disabilities is continually perpetuated in other ways - in unfounded assumptions about the abilities and performance of marginalized groups discriminatory, exclusive recruitment processes and the inaccessibility of the labour market. The concepts of undue hardship and reasonable accommodation may provide an escape "clause" for employers not to adhere to legislation. Accessibility and reasonable accommodation are also viewed as constraints as these inhibit persons with disabilities to compete on a more equal footing.

Further social challenges exist in many imbalances such as widespread ignorance, fear and stereotyping of the abilities of those considered to be "different", the lack of proper education, preparation, and integration of persons with disabilities as well as the lack of physical accessibility of the work place. These factors result in many persons with disabilities still being dependent on social security, with no regard for their dignity and selfesteem.

\section{The objectives of the article}

The article reviews the efficacy of labour legislation in South Africa in promoting the integration of persons with disabilities into the labour market, and control mechanisms, sanctions, or a lack of sanctions on businesses that fail to comply will be scrutinized. The practices and incentives will be considered against the reality of challenging economic imperatives. The economic impact of failing to integrate persons with disabilities into the labour market that results in dependency on social security structures would also be reviewed.

The changes as proposed in the newly proposed amendments to Labour legislation contained in the Employment Services Bill ${ }^{12}$ will be reviewed.

In conclusion amendments that will contribute to the efficacy and implementation of labour legislation to effect the goals envisaged by the EEA to achieve workplace equality will be proposed.

1 O'Reilly The Right to Decent Work of Persons with Disabilities (2007) Preface viii.

12 GG 358442 November 2012 [B38-2012]. 


\section{Definition and scope of disability}

The definition of disability is complex as persons with disabilities are not a homogeneous group; they may have a physical, sensory, intellectual or mental disability. The time of the onset of the disability, whether it was from birth, acquired in childhood, or later life, acquired during further education or while in employment will determine the ability to work or take part in society, or it may have a major impact, requiring considerable support or assistance.

The EEA defines people with disabilities as "people who have a long-term or recurring physical or mental impairment, which substantially limits their prospects of entry, or advancement in, employment". ${ }^{3}$

The Code of Good Practice further elaborates on this definition which will also be the focus group of this article: "The scope of protection for persons with disabilities in employment focuses on the effect of a disability on the person in relation to the working environment, and not on the diagnosis of the impairment". ${ }^{14}$

It is submitted that the definition of disability causes confusion and limitations to legislation and implementation of policies and legislation.

\section{Prevalence of disability in South Africa}

Following the increasing awareness of designated groups, the need arose to understand the prevalence of disability in the country. According to the Integrated National Disability Strategy (INDS) $)^{15}$ there is a serious lack of reliable information on the nature and prevalence of disability in South Africa. This is due to the fact that historically disability management was viewed within a health and welfare framework, leading to a failure to integrate disability into mainstream-government statistical processes.

The United Nations Development Programme (UNDP) and the Central Statistical Services (CSS) made an attempt to provide some insight into this challenge. The UNDP estimated that in 1990, 5.2 per cent of the world's population was experiencing moderate to severe disability; for South Africa the estimated figure stood at approximately 5 per cent in $1995 .{ }^{16}$

The population census conducted during 1996 included disability as a focus area and data indicated that 6.7 per cent of the South African population was disabled. ${ }^{17}$

The data collected in Census 2001 indicated that there were 2255982 people with various forms of disability. This number constituted 5 per cent of the total population enumerated in this census. ${ }^{18}$ Of this number, the African population recorded the highest number of disabled people (1 854376 or 5.2

\footnotetext{
EEA Ch 1 definitions.

14 EEA s 5 definition of people with disabilities.

1997 published by Department of Social Development.

16 Prevalence of Disability in South Africa, Statistics South Africa,1995 Report No 03-0244(2001) 6 (hereafter "Report on Prevalence of Disability").

17 Ibid.

18 Report on Prevalence of Disability 11.
} 
per cent), followed by white (191 693 or 4.5 per cent), coloured (168 678 or 4.2 per cent) and Indian/Asian (41 235 or 3.7 per cent). The number of females affected was 1173939 , compared to 1082043 males.

The prevalence of sight disability was the highest (32 per cent) followed by physical disability ( 30 per cent), hearing ( 20 per cent), emotional disability (16 per cent), intellectual disability (12 per cent) and communication disability (7 per cent) ${ }^{20}$

The new statistics of Census 2011 suggest that the percentage of persons over the age of four years with disabilities increased from 5.7 per cent in 2009 to 6.3 per cent in 2010 and then declined to 5.2 per cent in $2011 .{ }^{21}$ Statistics South Africa has advised users in an earlier report to treat the findings with caution, as it showed considerable variation. Statistics South Africa undertook to further investigate disability findings using data from the forthcoming GHS 2011. ${ }^{22}$ Available statistical data on prevalence of disability in South Africa is not comprehensive nor accurate. Estimates of the number of persons with disabilities in South Africa vary from 5.9 per cent to 12 per cent. $^{23}$

\section{SOUTH AFRICAN LABOUR LEGISLATION TO GIVE EFFECT TO EMPLOYMENT EQUITY FOR PERSONS WITH DISABILITIES}

"I was slightly brain damaged at birth, and I want people to like me, to see that they shouldn't let a disability get in their way. I want to raise awareness - I want to turn my disability into ability." Susan Boyle

The advent of democracy in 1994 was marked by conscious attempts to redress the social inequalities of the apartheid era. One of the paramount objectives of the democratic Government has been to complement the fundamental rights in accordance with the Constitution. The Government of the time proposed several social policies to address this.

In legal terms, the most compelling reason for the reforming of the labour legislation was the requirements of the interim Constitution. ${ }^{24}$ Chapter 3 of the interim Constitution, the "Bill of Rights", entrenched certain fundamental rights such as the right to equality and the freedom to engage in economic activity. ${ }^{25}$ The South African labour arena required apt labour legislation to address the disparities in the labour market. This needed to be in tune with International Human Rights Law and the International Labour Organisation as the new Government committed itself to upholding international labour standards and undertook to submit to the ILO Conventions.

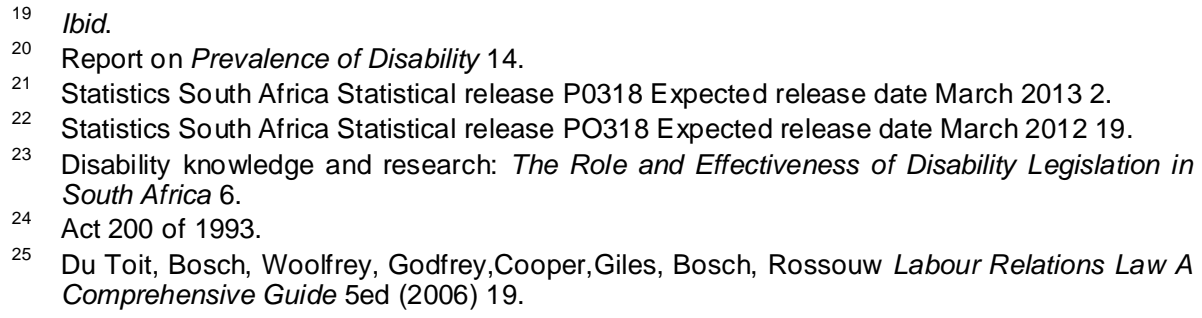




\section{The United Nations (UN) and the International Labour Organisation (ILO)}

One of the most significant contributions of the UN is the Universal Declaration of Human Rights which was adopted in 1948.

The right of everyone to work, including persons with disabilities, was confirmed by the UN. The Universal Declaration of Human Rights confirms: "Everyone has the right to work, to free choice of employment, to just and favourable conditions of work and to protection against unemployment. Everyone, without discrimination, has the right to equal pay for equal work. Everyone who works has the right to just and favourable remuneration ensuring for himself and his or her family an existence worthy of human dignity, and supplemented, if necessary, by other means of social protection." ${ }^{26}$

The early focus of the organisation on disability revolved around a paradigm of welfare and rehabilitation, however, the focus progressively changed to a rights-based paradigm with equality as its driving force. ${ }^{27}$ Internationally the UN launched its World Programme of Action concerning Disabled Persons many years later, and in 1982 the General Assembly adopted the World programme of Action Concerning Disabled Persons that was to guide the United Nations' adopted Decade of Disabled Persons (1983-1992) ${ }^{28}$ At the time the South African Government did not recognize the United Nations programme and this led to the uprise of a disability-rights movement in South Africa. ${ }^{29}$ As the apartheid Government did not recognize the UN 1981 International Year of Disabled Persons, instead, 1986 was declared the national Year of the Disabled and the Government established a committee on Disability (ICCD) to advise Government on policy reform. In 1997, the Government adopted the White Paper on an Integrated National Disability Strategy known as the INDS. The INDS represented a paradigm shift away from the medical or welfare-model of disability. The INDS guided Government and society as a whole with guidelines that will promote nondiscriminatory-development planning, programme implementation and service delivery. ${ }^{30}$

\section{The International Convention on the rights of persons with disabilities}

The most recent and most significant contribution by the UN to address disability management was the response acknowledging the rights of persons with disabilities when The United Nations General Assembly adopted the Convention on the Rights of Persons with Disabilities (ICRPD) ${ }^{31}$

26 UN, Universal Declaration of human rights, adopted by the General Assembly on 10 December 1948 (Article 23).

27 Dupper and Garbers (eds) Equality in the Workplace Reflections from South Africa and Beyond (2009) 184 (hereinafter "Equality in the Workplace")

28 Dupper and Garbers Equality in the Workplace 186.

29 INDS 15.

30 The Role and Effectiveness of Disability Legislation in South Africa 17.

31 UN Resolution A/RES/61/06. 
on 13 December 2006. South Africa ratified both the Convention and the Optional Protocol to the Convention on 30 November $2007,{ }^{32}$ showing its clear commitment to national and global implementation thereof. This Convention aims to "promote, protect and ensure the full and equal enjoyment of all human rights and fundamental freedoms of persons with disabilities, and to promote respect for their inherent dignity". ${ }^{33}$ The Convention determines that state parties should recognize the right of persons with disabilities to work, on an equal basis with others. This includes the right to the opportunity to gain a living by work freely chosen or accepted in a labour market and a work environment that is open, inclusive and accessible to persons with disabilities. State parties are expected to safeguard and promote the realization of the right to work, including those who acquire a disability during the course of employment, by taking appropriate steps, including through legislation. ${ }^{34}$

It is important to review the normative implications of the Convention for South Africa, with focus on substantive norms for the achievement of equality and elimination of unfair discrimination against disabled people with special reference to the workplace. Disability is a listed ground to have protection against unfair discrimination under the South African Constitution. ${ }^{35}$ What is the understanding of equality as a normative value and right in regard to disability in the Convention?

Also how does the understanding of the convention impact on South Africa in terms of consonance or dissonance with equality norms and standards under the Constitution and the Employment Equity Act? ${ }^{36}$ To the extent that South Africa has ratified the Optional Protocol, and further that the South African constitution requires courts to consider international law, when interpreting the Bill of Rights. ${ }^{37}$

We argue that the Convention is an important contribution towards promoting the understanding of what is entailed in respecting, protecting and fulfilling the right to equality as it applies to persons with disabilities under South African jurisprudence. ${ }^{38}$ The Convention is merely viewed as a complementary instrument and does not introduce substantive new jurisprudence into South African equality jurisprudence, but adds value in reinforcing substantive equality. ${ }^{39}$ South African disability jurisprudence is still in an emerging stage, as courts have rarely had the opportunity to adjudicate on cases involving disability as a non-discriminatory national issue. $^{40}$

The Convention is of great value in its articulation of disability, specifying equality concepts. It is apt to raise awareness and understanding about

32 United Nations enable: The Convention on the rights of Persons with disabilities http://www.un.org/disabilities/default.asp?id=257 (accessed 2012-12-27).

3 Art 1 of the Convention.

Art 27 of the Convention.

S 9(3) and (4).

Dupper and Garbers Equality in the Workplace 183

The Constitution s 39(1)(b)

Dupper and Garbers Equality in the Workplace 182

Ibid.

Ibid. 
disability-specific equality concepts, not just for interpretation of the law or in disability advocacy, but also for general awareness and understanding about remedying the socio-economic exclusion of people with disabilities. ${ }^{4}$

The Convention is seen to be a progressive instrument that addressed the failures of other instruments such as the International Covenant on Civil and Political rights (ICCPR) and the International Covenant on Economic, Social and Cultural Rights (ICESCR) to address equality for persons with disabilities. ${ }^{42}$

It is described as a conscious attempt at designing a human-rights instrument that not only seeks to overcome the historical invisibility of disability in human-rights treaties, but also seeks to recognize nonhierarchical equality in human difference and the imperative of normative inclusion of persons with disabilities in a plural society.

\section{The ILO Conventions specifically addressing disability in the workplace}

\section{Vocational Rehabilitation and Employment of Disabled Persons (159 of 1983)}

In 1983, since the adoption of the Vocational Rehabilitation Recommendation of 1955 , significant developments have occurred in the understanding of rehabilitation needs: in the law and practice. Considering that 1981 was declared by the United Nations as the year of the Disabled Persons, with the theme "full participation and equality" and that a comprehensive World Programme of Action concerning Disabled Persons followed, was to provide effective measures at international and national levels for the realization of goals of "full participation" of disabled persons in social life and development. ${ }^{44}$ The underlying labour standards contained in this convention, provided the principles contained in the Code of Good Practice on managing disability in the workplace. ${ }^{45}$

\section{ILO Code of Practice on Managing Disability in the Workplace (2002)}

The preface of the Code clearly indicates that the code has been drawn up to guide employers - the large, medium or small-sized enterprises, including private and public sector, in developing or highly industrialized countries - to adopt a positive strategy in managing disability-related issues in the workplace.

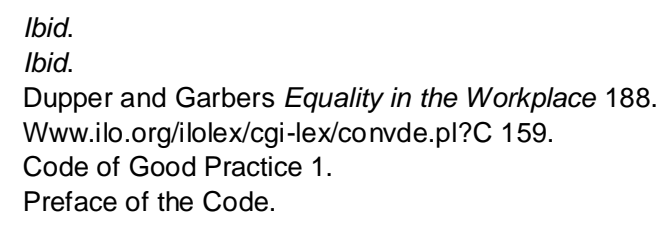




\section{ILO Human Resources Development Recommendation (195 of 2004)}

The Recommendation mainly deals with the challenges posed by globalization, such as the so-called "brain drain", which is causing concern in many developing countries. It calls for international mechanisms that would mitigate the adverse impact on developing countries by the loss of skilled people. It also recognizes that education and training strategies and creating the right enabling conditions - economic growth, investment, creation of decent jobs and human development - that will assist countries in retaining skilled labour.

The Recommendation is built on a number of core principles that reflect the ILO's values: that education, training and lifelong learning contribute significantly to promoting the interests of people, enterprises, the economy and society as a whole; that lifelong learning contributes to personal development, access to culture and active citizenship; it confirms that the social partners have roles to play and commitments to fulfil in support of lifelong learning. It acknowledges that many developing countries should be assisted to design, fund and implement education and training policies for economic and employment growth in the attempt to eradicate poverty. It confirms that the realization of decent work for workers everywhere is a primary objective of the ILO. ${ }^{48}$

The instrument makes special mention of rights and recognizes that education and training are that for all people. It further advises on policies that ensure persons with special needs have access to education, training and lifelong learning that will be powerful tools to liberate them economically and socially.

The international guidelines by the ILO provided direction and paved the way for South Africa to action apposite legislation to support the international conventions.

\section{The Constitution of South Africa}

The adoption of the Constitution ${ }^{49}$ in 1996 brought about a mayor change to the face of the South African legal system. ${ }^{50}$ It is the highest law and acts as the custodian of all legislation and subordinates all to its provisions. It further restrains the legislature from unreasonably encroaching on the individuals' rights as contained in Chapter Two, the Bill of Rights.

The Constitution acknowledges in section $9(1)$ the right to equality: "Everyone is equal before the law and has the right to equal protection of the law". Implicit in this right is the understanding that neither the State nor any other person may discriminate, directly or indirectly, against anyone on various arbitrary grounds listed, including race, gender, sex, pregnancy,

\footnotetext{
ILO Recommendation 195 of 2004 Preface Juan Somavia, Director General. 
marital status, ethnic or social origin, colour, sexual orientation, age, religion, disability, religion, conscience, belief, culture, language and birth.

The heart of the South African Constitution is based on the notion of equality before the law. It is integral to the vision of society established in the preamble, and is entrenched as both a value and a legally enforceable right. $^{52}$

Section 9 sets out a detailed right offering substantive protection against unfair discrimination or differentiations made on the basis of prohibited grounds. Section 9(3) as well as (4), includes disability, and prohibiting any other classification made on any other basis than section 9(1). Section 9(2) provides for positive and remedial equality enabling positive measures to advance equality, and provides the Constitutional imperative for the affirmative-action provisions in the Employment Equity Act. ${ }^{53}$

From the right to equality as contained in the Constitution flow further rights, including the right to dignity, ${ }^{54}$ right to freedom and security, ${ }^{55}$ freedom of trade, occupation and profession ${ }^{56}$ amongst others.

The promise in the Constitution "to improve the quality of life of all citizens and to free the potential of each person" ${ }^{\prime 57}$ applies to persons with disabilities as to all other social groups.

The Constitution specifically deals with labour and employment rights in section 23 which confers on "everyone" the right to fair labour practices thus requiring the South African legislature to redress labour legislation and to adopt an approach that would confirm the notion of equality with the aim to prevent discrimination.

It is contended that the Constitutional recognition of the right not to be discriminated against does, however, not afford sufficient protection. Owing to the nature of a constitution it does not define the protected class or concepts relevant to the protection of people with disabilities. It thus requires to be supported by additional anti-discrimination legislation. ${ }^{58}$

The Constitution thus paves the way and instructs as per section 9(4) the legislature to "enact national legislation to prevent or prohibit unfair discrimination". In an attempt to review the unfolding of the legislation to follow it is necessary to review the history of the legislation under the previous dispensation.

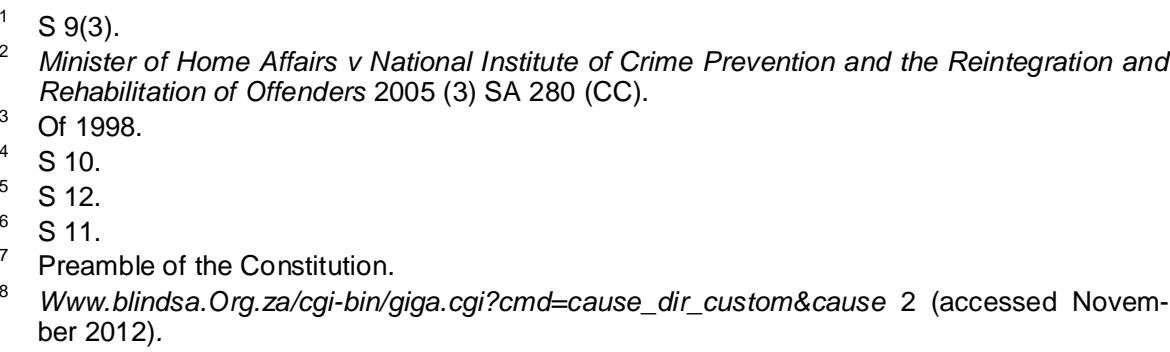




\section{Labour Relations Act 28 of 1956 (1956 LRA)}

This Act contained no explicit prohibition of discrimination in the definition of an unfair labour practice and provided no protection for applicants. Employers were at liberty to refuse an applicant on the basis of gender, race, inter alia disability. Applicants for employment enjoyed no protection or legal standing (locus standi) under the 1956 LRA to declare a dispute with an employer even though he/she had been the victim of unfair discrimination. In fact some legislative provisions ${ }^{59}$ specifically permitted discrimination in employment. ${ }^{60}$

The interim Constitution, ${ }^{61}$ section 8 , paved the way for a guarantee that the law will contain a section that will protect and benefit people equally, and contained a specific prohibition on unfair discrimination. In addition, it provided for measures designed to achieve the protection and advancement of people previously marginalized and disadvantaged by unfair discrimination.

While it was possible after 1981 to bring a discrimination claim under the rubric of the unfair labour-practice definition of 1956 LRA, the industrial Court seldom had the opportunity to adjudicate discrimination claims. ${ }^{62}$

\section{Labour Relations Act 66 of 1995 (LRA)}

The LRA was the first step in the Department of Labour's original five year plan to the reform of labour legislation. ${ }^{63}$ This Act aims to encourage collective bargaining and settlement of disputes; it also enhances the powers of the forums designed to facilitate these objectives. ${ }^{64}$ Previously discrimination was included in as a form of "residual unfair labour practice" definition of the LRA. This prohibition was removed from the LRA and repromulgated in the Employment Equity Act. ${ }^{65}$

The Labour Relations Act 1998 provides for the regulation of unfair treatment in the workplace via a provision on unfair labour practices.

Employees may institute action for automatic unfair dismissal under the LRA, dismissal for incapacity and disability. It should be clearly distinguished between an employee who is incapacitated ${ }^{66}$ compared to an employee with a disability. ${ }^{67}$ The employer's corresponding obligations to each situation differ materially. The Act, however, makes provisions for dismissal, inter alia, on grounds of incapacity due to ill health or injury. Schedule $8^{68}$ contains in article 10 and 11, guidelines on dealing with incapacity and ill health. The

\footnotetext{
Such as the Wage Act 5 of 1957 and the Industrial Conciliation Act 28 of 1956.

Dupper et al Essential Employment Discrimination Law 9.

200 van 1993.

Dupper et al Essential Employment Discrimination Law 10.

Du Toit et al Labour Relations Law A Comprehensive Guide 33.

Grogan Employment Rights 6.

Grogan Employment Rights 7.

$S$ 188(1).

$S 1$ of the EEA.

The Code of Good Practice: Dismissal.
} 
duration and extent of the incapacity determine the employer's obligation. It is incumbent on the employer to explore options short of dismissal where the employee is expected to recover within a reasonable period of time. ${ }^{69}$ However, when the incapacity is permanent, the employer is to explore continued employment via alternative employment or adaption of duties or work circumstances. ${ }^{70}$ It may be necessary in some circumstances to distinguish between incapacity and disability to determine the need to accommodate or the fairness of a dismissal. In NEHAWU obo Lucas and the Department of Health (Western Cape) $)^{71}$ the arbitrator examined the employment of persons with disabilities and the duty of the employer to accommodate. It was found, that although the employee did not cooperate in the process, the employer did not have substantive reason to terminate the relationship and the dismissal was therefore found to be unfair. ${ }^{72}$ The degree of incapacity also plays a role, and in accordance with the code 10(3) an employer cannot be expected to continue to employ an employee who is no longer productive.

The nature and the size of the business will also be a decisive consideration. The obligation on a small business is less onerous to make accommodation as determined in the matter of Philander $v$ Eco Car Hire $C C{ }^{73} \mathrm{~A}$ distinction was indicated that an injury on duty requires more tolerance from the employer. In Carr $v$ Fisons Pharmaceuticals, ${ }^{74}$ an employee had been injured on duty and the employee was dismissed as she was no longer able to fulfil her duties, but without any consultation. The dismissal was held to be unfair. In Tither $v$ Trident Stee $P^{75}$ the arbitrator found that employers may not dismiss employees without making a serious effort to adapt the employee's duties or position or to find alternative work. The dismissal was found to be substantively fair, but procedurally unfair. In Standard Bank of South Africa $v C C M A^{76}$ the court found that that the employer had the premise to end the relationship and pursued actions to do so. The employer's obligation, however, was to demonstrate intent to continue the relationship. In the process the employer failed to explore reasonable accommodation of the employee and the dismissal of the employee for incapacity was automatically unfair. Dismissal must be the last option. In cases such as these. The onus is on the employer to show that it has made every attempt for reasonable accommodation. Pillay $\mathrm{J}$ held as follows -

"The search for accommodation is a multi-party inquiry. Although the principal responsibility for conducting the enquiry rests with the employer, at the very least, the employer must confer with the disabled employee, her trade union or workplace representative ..."77

Beaumont, Beaumont Workshop (Spring 2008) 18.

Ibid.

(2004) 25 ILJ 2091 (BCA).

72 Basson, Christianson, Dekker. Garbers, Le Roux, Mischke, Strydom Essential Labour Law 5ed (2009) 146.

[2001] 6 BALR 631 (CCMA).

74 (1995) 16 ILJ 179 (IC).

[2004] 4 BALR 404 (MEIBC).

[2008] 4 BLLR 356 (LC).

Standard Bank of South Africa v CCMA supra par 91. 


\section{Employment Equity Act 55 of 1998 (EEA)}

The EEA is a product of South Africa's history and recent attempt of the legislature to give expression to the commitment to eradicate the inequality of the past. ${ }^{78}$ The EEA is meant to give expression to the broader constitutional right to equality as enshrined in section 9 of the Constitution adapted to fit the workplace context, ${ }^{79}$ and further aims to give effect to the obligations of the Republic of South Africa as a member of the ILO. ${ }^{80}$ The Act's purpose is to achieve equality in the workplace by promoting equal opportunity and fair treatment in employment ${ }^{81}$ on the one hand, and to eradicate all forms of unfair discrimination and on the other hand, in correcting the demographic imbalances in the nation's workforce. ${ }^{82}$ It further purposes the implementation of affirmative-action measures to redress the disadvantages in employment experienced by designated groups, in order to ensure their equitable representation in all occupational categories and levels in the workplace. ${ }^{83}$ The EEA consists of two sections:

Chapter II of the Act deals with the prohibition of unfair discrimination on several arbitrary grounds, including disability. The Act interestingly contains no definition of the word "discriminate". The addition of the adjective "unfair" in section 6(1) implies that some forms of discrimination may be fair, or at least be not necessarily unfair. ${ }^{84}$ The Constitutional Court has held that "discrimination" denotes the potential to impair the fundamental dignity of persons as human beings or to affect them adversely in a comparably serious manner. $^{85}$

An investigation into a claim of unfair discrimination involves a two-stage inquiry. ${ }^{86}$ The first to establish if there was discrimination the second whether the discrimination was in fact unfair. Section 11 of the EEA states that "whenever unfair discrimination is alleged in terms of the Act, the employer against whom the allegation is made must establish that it is fair" ${ }^{87}$ This suggests that the onus of proof is on the employer, however, this does not vary the general rule that the person who alleges must prove the allegation. ${ }^{88}$ It merely confirms that the individual (employee) will first have to prove prima facie that discrimination indeed took place.

Chapter III of the Act goes further than just proscribing unfair discrimination, as it sets out the means by which "designated employers" 89 must implement affirmative action in favour of designated groups. It further

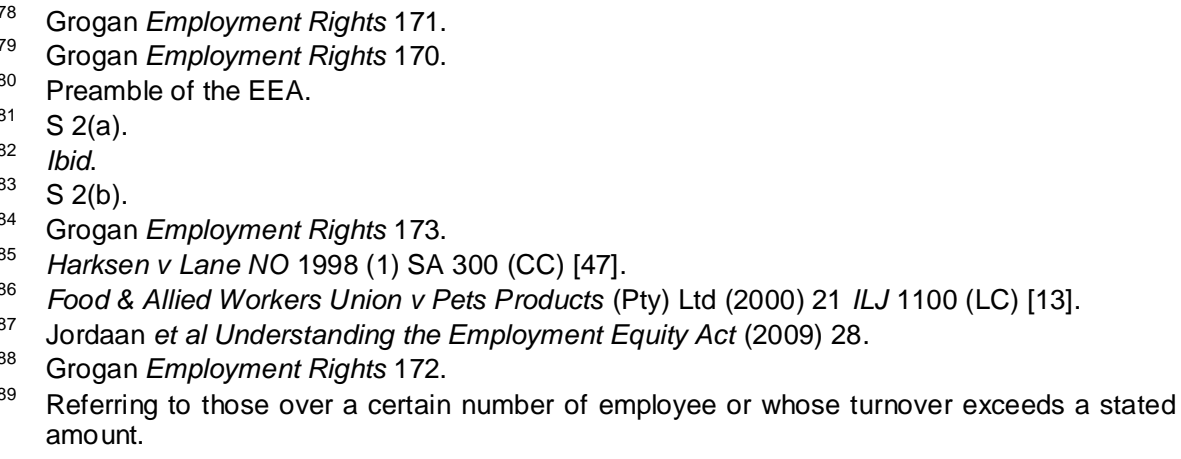

Referring to those over a certain number of employee or whose turnover exceeds a stated amount. 
compels employers to remove barriers to the advancement of previously disadvantaged groups, ${ }^{90}$ and actively promote them in all categories of employment by affirmative action. The EEA also requires that equity plans should state the time frame within which equity will be achieved where under-representation of people from designated groups have been identified. Affirmative action as a defence in terms of discrimination must be consistent with the purposes of the EEA. ${ }^{1}$

This process must take place by consulting with their employees, adopting equity plans and implementing them according to agreed targets. An equitable workplace according to the Act is one with a workforce that more or less approximates the demographics of the population as a whole.

In the context of the designated group of people with disabilities it is important to note that the EEA is the only statute that expressly includes applicants for employment.

It is, however, argued that affirmative-action programmes should not be abused as protection will fall away when the effects of past discrimination have been removed, and equality achieved as indicated in the matter of Reynhard $v$ University of South Africa ${ }^{92}$ It is also suggested that an employer should engage in affirmative action as understood by the Act, instead of making token appointments from disadvantaged groups merely to promote its image or gain access to the markets. ${ }^{93}$ This practice of "token appointments" would affect the dignity of the designated group and would be in contradiction with the ethos of equality legislation. The use of the word "equal" has been held to denote that the interests of the beneficiaries are not to be considered in vacuo, but should have regard for the rights of others and the interest of the community, and to the possible disadvantage that the targeted persons or groups may suffer. ${ }^{94}$

The legitimate defence afforded to employers under the Act is the inherent requirements of the job. ${ }^{95}$ This provision recognizes that it is not unfair to "distinguish, exclude or prefer any person on the basis of an inherent requirement of the job", it recognize that there may be situations in which possession of one or other of the characteristics listed in 6(1), or lack thereof, may be relevant to certain positions or work. The word "inherent" suggests that possession of a personal characteristic (for example being male, female, speaking a particular language, being free of a disability) must be necessary to perform the duties attached to a particular position effectively. ${ }^{96}$ An example of such is customer preference. However, in South Africa the Constitutional Court has held that the values of equality and human dignity far outweigh considerations such as customer preference. ${ }^{97}$

\footnotetext{
This includes ("blacks", "coloureds", "Indians", woman and the disabled).

$\mathrm{S}(6)(2)(\mathrm{a})$

(2008) 29 ILJ (LC).

Grogan Employment Rights 200.

Public Servants Association of SA v Minister of Justice (1997) 18 ILJ 241.

$S(6)(2)(b)$.

Grogan Employment Rights 200.

Hoffmann v SA Airways (2000) 21 ILJ 2357 (CC) [33]-[37].
} 
Indications are that the courts set the requirements for this defence quite high. In IMATU $v$ City of Cape Town, ${ }^{98}$ a case that refers to a blanket ban on employment of "type 1" diabetics as fire-fighters, the court accepted the following as examples of unacceptable criteria:

- evaluation of a person's competence for a task on the basis of stereotypes of the group to which the employee belongs;

- requirements based on preferences of employees and clients;

- requirements that a task should be performed in a particular way when the employee may be able to do it in other ways;

- qualifications based on the distinctions between the ability to perform "light" or "heavy" work.

The only reported judgment case on discrimination on the grounds of disability sets the tone for the defence of people with disabilities. The lesson that emerges from this case is that if employers wish to exclude categories of employees on the basis of health, they must prove that they are incapable of meeting the requirements of the job, or that they are susceptible to a much higher risk than other employees failing to meet these requirements in circumstances they are likely to encounter while pursuing their career. This applies whether or not the condition concerned is strictly classified as a disability.

The EEA also places an obligation on an employer to make reasonable accommodation in respect of people from designated groups in order to ensure that they enjoy equal opportunities and are equitably represented in the workplace. ${ }^{100}$ Failure to do so could constitute unfair discrimination, where it would not lead to undue hardship for the employer. This may include amending rules and policies.

\section{Code of good practice - on the employment of people with disabilities}

The Code of Good Practice officially launched on 19 August 2002, was established in line with the Employment Equity Act. No 55 of $1998 .{ }^{101}$

The Code is clear about the fact that it is not an authoritative summary of the law, nor does it create additional rights and obligations. ${ }^{102}$ However, it goes further to state that the courts and tribunals that interpret and apply the Employment Equity Act must consider the code. ${ }^{103}$ Perhaps one of the most valuable uses of the Code is that it is intended for employers and employees and their organizations to develop, implement and refine disability-equity policies and programmes to suit the needs of their own workplaces.

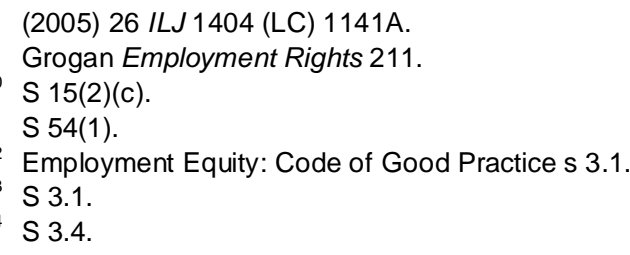


Failure to observe the code does not in itself render a person liable in any proceedings, rather, the Code is there to answer to the employer on how disability in the workplace should be defined and managed. The Code is informed by the underlying principles of the International Labour Organization standards as contained in the Vocational Rehabilitation and Employment Convention of 1983.

This was an attempt by Department of Labour to assist employers to comply with the EEA and transcribe the obligations in terms of persons with disabilities to the workplace and potential employers.

\section{Technical-assistance guidelines on the employment of people with disabilities}

The Technical Assistance Guidelines on the Employment of People with Disabilities (TAG) are intended to complement the Code of Good Practice on the Employment of People with Disabilities. Its intention is to build on the Code to set out practical guidelines and examples for employers, employees and trade unions on how to promote equality, diversity and fair treatment in employment through elimination of unfair discrimination. ${ }^{105}$

The TAG should be seen as part of the broader equality agenda for people with disabilities to have their rights recognized in the labour market. ${ }^{106}$ The Code and the TAG form the basis for the implementation of the provisions of the Act. These are the documents that will be used to guide employers in the implementation of the Act and will be used to guide the Courts where disputes may arise. ${ }^{107}$

With the launch of the TAG on 3 November 2003, Minister Mdladlana, Minister of Labour at the time, referred in the keynote address to the fact that the Portfolio Committee on Labour, reported on the failure of business to making significant advances towards the employment and promotion of people with disabilities. ${ }^{108}$

The Minister further promised that the Department "is at the moment making advances to close all loopholes in order to make it difficult for employers to have excuses in the implementation of affirmative action, with special focus on people with disabilities". ${ }^{109}$

Considering the time frames and that the fact that the little progress has since been made this promise seems to be still unfulfilled.

\section{Basic Conditions of Employment Act 75 of 1997 (BCEA)}

The purpose of the BCEA is to advance economic development and social justice as it sets out to give effect to the right to fair labour practices as

\footnotetext{
${ }^{105}$ Foreword M M S Mdladlana Minister of Labour in the TAG.

106 Foreword.

107 TAG 5.

108 Http://www.polity.org.za/article/mdladlana-launch-of-techinical-assistance-guidelines.

109 Ibid.
} 
referred to in section 23(1) of the Constitution by establishing and making provision for the regulation of basic conditions of employment.

This Act can give assistance to an employer to provide reasonable accommodation to the employee with disabilities, for example to adjust working conditions for People with Disabilities such as weekly rest periods and sick-leave provisions. However, the Act makes no allowances or specific provisions for disabled employees.

\section{The Promotion of Equality and Prevention of Unfair Discrimination Act 4 of 2000 (PEPUDA)}

The Act drafted to give effect to section 9(4) of the Constitution, read with item 23(1) of Schedule 6 to the Constitution of the Republic of South Africa, 1996, so as to prevent and prohibit unfair discrimination and harassment; to promote equality and eliminate unfair discrimination; to prevent and prohibit hate speech; and to provide for matters connected therewith. ${ }^{11}$

This Act is a wide-ranging act and although it is a further attempt to prohibit unfair discrimination, it is not intended to overlap or displace the EEA that governs equity in the workplace. ${ }^{112}$ PEPUDA impacts on the workplace as it broadens the base as it covers matters that are not covered by the EEA, and it in addition covers employees and their employers that are excluded from the EEA.

The Act also attempts to ensure that Persons with Disabilities are treated with respect and should enjoy similar rights as non-disabled people. The Act indentifies unfair practices such as creating artificial barriers to employment opportunities or applying human-resource practices which unfairly discriminated against persons from identified groups on prohibited grounds. One of the listed grounds of prohibition is disability and is specifically dealt with in section 9 of the Act. ${ }^{113}$

The objectives of the Act make it clear that the intention of the legislation is, amongst other things, to "give effect to the letter and spirit of the Constitution", to promote equality and to promote the "equal enjoyment of all rights and freedoms by every person". ${ }^{114}$

10 Purpose of the Act.

11 Introduction to the Act.

112 Dupper et al Essential Employment Discrimination Law 287.

113 Prohibition of unfair discrimination on ground of disability:

9. Subject to section 6 , no person may unfairly discriminate against any person on the ground of disability, including -

(a) denying or removing from any person who has a disability, any supporting or enabling facility necessary for their functioning in society;

(b) contravening the code of practice or regulations of the South African Bureau of Standards that govern environmental accessibility;

(c) failing to eliminate obstacles that unfairly limit or restrict persons with disabilities from enjoying equal opportunities or failing to take steps to accommodate the needs of such persons.

114 S 2(b)(i)-(iii). 
In theory and in accordance with the Act, the designated group may have recourse under this act to take on an employer who does not make his workplace accessible for people with disabilities to access employment. Considering the position of this already marginalized group this approach is unlikely to be accessible to people with low literacy levels and/or formal education, who are most likely unable to access legal services to vindicate their rights claims. Perhaps only a selected group that have access to lawyers and or cases that are taken up by public-interest groups will ever be heard. Given the level of poverty in South Africa it is likely that a vast majority of rights claimants will remain unassisted.

\section{The Protected Disclosures Act (26 of 2000)}

To conceal or disclose a disability is an important aspect regarding the employment of persons with disabilities, yet it is an ethical dilemma. The South African Constitution makes provision for the right to privacy, ${ }^{115}$ however, disclosure makes provision for the employer to make reasonable accommodation and allowance conducive to working conditions. The Bill of Rights affords the individual the right to informational privacy. The right is related to reasons for protecting human dignity and control over private information.

There is thus no obligation on the individual to disclose he/she disability status or whether he/she requires adjustment to be made to the workplace environment. However, employees can only require adjustment to be made provided they disclose their disability status, or if the status is self-evident to the employer. The intention of this Act was to make provision for procedures in terms of which employees in both the private and public sector may disclose information regarding unlawful or irregular conduct by employers or other employees, and equally to provide for the protection of employees who make such a disclosures.

Section 1(i) is applicable to cover persons with disabilities. Section (3) also states that "no" employee may be subjected to any occupational detriment by his or her employee on account of having made a protected disclosure. ${ }^{116}$ The Act further confirms that such employee may not be denied appointment to any employment, profession or office.

The guidelines provided by the Code of Good Practice ${ }^{117}$ and the TAG serve as important tools to assist the employer in developing ways on how to deal with the disclosed information of the person with a disability. This should assist the employer in making informed decisions about providing reasonable accommodation for persons with disabilities in the workplace.

The Protected Disclosure Act can serve as a guideline to provide further protection to refrain employers from discrimination against persons with disabilities after having made a disclosure about their disability. The manner in which the employer treats confidentiality and records regarding such information should solicit trust regarding a person with a disability to disclose

117 TAG 51. 
information about her/his disability. The employer should also exercise caution in regard to whom may have access to this information.

\section{Skills Development Act 97 of 1998}

This Act addresses and provides for the legal framework wherein the State assumes responsibility for the training of workers and is tied to the capacitybuilding strategy encapsulated in the EEA. ${ }^{118}$ One of the purposes of the Act is to improve the employment prospects of people previously disadvantaged by unfair discrimination and to redress disadvantages through training and education.

Persons with disabilities amongst other disadvantaged and the targets set in the National Skills Development Strategy set should be 85 per cent black, 54 per cent female and 4 per cent persons with disabilities. Evaluation of these target figures indicates that (0.04 per cent) achieve Level One of the National Qualifications Framework (NQF). This number is still significantly under the target. ${ }^{19}$ The Code of Good Practice states that the ways by which unfair discrimination is perpetuated are inappropriate and inadequate training of persons with disabilities, as well as failing to ensure that the company's training courses are fair and accessible to employees with disabilities.

Another purpose of the Act is to provide opportunities for new entrants to the labour market to gain work experience, and to provide opportunities to employ people who find it difficult to be employed, such as persons with disabilities. Since many of the employable persons with disabilities have very little skills and exposure to the labour market the TAG states that employers must consider offering learnerships or additional training to "high-potential candidates". ${ }^{120}$

The Skills Development responsibility falls under the auspices of the Department of Higher Education, and training is facilitated through some twenty-odd SETA's, that operate through a levy-and-grant system as determined by the Skills Development Levies Act (SDLA).

In response to the view that there is considerable scope to increase the employment of persons with disabilities within the Fasset ${ }^{122}$ sector. This SETA proactively provides for substantial deductions ${ }^{123}$ that can be claimed from the South African Revenue Services for a learner with a disability. The SETA further provides a Learnership Cash Grant, Strategic-Cash grant, SMME Grant and special project funding for each learner with a disability.

118 TAG 42.

119 The Role and Effectiveness of Disability Strategy Legislation in South Africa 8.

120 TAG 42

121 Act 9 of 1999. According to this Act, every employer in South Africa with a payroll exceeding R500 000,00 per annum is liable to register for Compulsory Skills Development Levy (SDL) that amounts to 1 per cent of the total payroll as calculated for the Pay-As-You-Earn (PAYE) tax. This includes staff who fall below the PAYE threshold, but excludes registered learnership staff.

122 Finance, Accounting, Management Consulting and Other Financial Services sector.

123 Learners with a disability commencement allowance R50 000 per annum, completion allowance R50 000 per annum multiplied by the number of completed 12-months periods. 
Although the sector employs only a small number of people with disabilities the type of work performed in the sector lends itself to the training of larger numbers of persons with physical disabilities. By recruiting persons with disabilities employers will not only meet the skills needs within the sector, but they may also be able to support national policy legislation, such as employment-equity targets, Corporate Social Responsibility Initiatives (CSRI) and Broad-Based Black Economic Empowerment (B-BBEE) targets. In addition, employers are able to benefit from higher SARS learnership deductions for each year of the learnership that has been registered and completed as well as possible LCG amounts for these learners. ${ }^{124}$

Employers are able to improve a company's rating in terms of the Department of Trade and Industry's (DTI) codes. Skills development forms 20 per cent of the weighting in (DTI) B-BBEE Codes. Skills development can in addition contribute a substantial number of points to the DTI's codes and to the training and development of Persons with Disabilities. ${ }^{125}$

The aforementioned financial benefits are not of prime importance, but nevertheless valuable to the receivers. Relevant to the economic rationale of a company these are not well publicised, following that very little appropriate information in this regard is available. This could be a persuasive tool in assisting companies to give preference to applicants with disabilities.

\section{Occupational Health and Safety Act 85 of 1993}

This Act in essence replaces the common-law duty of employers to provide and maintain a safe and healthy environment for all employees and employers covered by it. The Act does not make any special provision for Persons with Disabilities in the Workplace. The only guidance in terms of Health and Safety issues relating to disability is found in the TAG. ${ }^{126}$ It advises that as part of an ongoing health and safety audit within a workplace, the needs of employees with disabilities must be included. Evacuation procedures should take into account any specific or additional measures to ensure that an employee with a disability is safely evacuated from a building or worksite during emergencies.

Special needs and reasonable accommodation are often related to health and safety issues. The lack of guardrails, for example, may present a severe threat to the blind. However, these do not have to be onerous as a review of standard safety procedures such as fire evacuations, lift-operating procedures, door sensors and warning of glass doors will confirm that these measures are in place.

This Act seems to lack information relating to the health and safety of persons with disabilities and makes no provision for the special needs of this group and no proviso for enforcement for special-needs safety.

\footnotetext{
FASSET Disability Toolkit 10.

Disability Toolkit 8-10.

126 TAG 17.
} 


\section{Social Security Legislation}

The South African Constitution ${ }^{127}$ confirms the right for everyone to have access to social security, and including, if they are unable to support themselves and their dependants, appropriate social assistance. ${ }^{128}$ The South African social-security system comprises of the different socialsecurity schemes ${ }^{129}$ that mainly focus on paying compensation and paying other benefits and expenses flowing from an incident, for instance medical expenses. ${ }^{130}$ This legislation is aimed at compensation while the important objects of prevention and integration are not considered. According to Jordaan et al social security is not merely curative (in the sense providing compensation) but also preventative and remedial in nature. The focus should be on the cause of social insecurity (in the form of, amongst others, social exclusion or marginalization) rather than on (merely dealing with) the effects. $^{131}$

Employees have rights not only against their employers but also against the State, which in the capacity of guarantor of the well-being of all citizens has assumed responsibility for the care of employees who lose their employment or who are injured while on duty. ${ }^{132}$

The main instruments for the discharge of this responsibility in terms of social insurance are the Unemployment Insurance Act ${ }^{133}$ (UIA) and the Unemployment Contributions $\mathrm{Act}^{134}$ (UICA), and special legislation covers specific aspects of Occupational Diseases in Mines and Works Act. ${ }^{135}$ The Occupational Health and Safety Act (OHSA), ${ }^{136}$ and the Mines Health and Safety Act $(\mathrm{MHSA})^{137}$ deal with preventative and standard-setting framework in respective the non-mining and mining sectors. The Road Accident Fund, ${ }^{138}$ which is primarily funded from a compulsory fuel levy, pays out compensation for loss or damage suffered as a result of any bodily injuries or death, caused by negligent driving of motor vehicles. The State makes further provision in terms of social-assistance benefits that are provided in terms of the Social Assistance Act. ${ }^{139}$ This assistance includes amongst others a disability grant. However, the legal system restricts large parts of social insurance to the formal employment context. It excludes many from

S 27(1)(c).

Jordaan, Kalula and Strydom (eds) Juta's Pocket Companions Understanding Social Security (2009) 1.

129 Such as the schemes for social assistance, unemployment insurance and compensation for occupational injuries and diseases.

130 Jordaan et al Understanding Social Security 5.

131 Jordaan et al Understanding Social Security 7.

132 Grogan Employment Rights 8.

13363 of 2001.

1344 of 2002.

13578 of 1973 .

13685 of 1993 .

13729 of 1993.

138 Regulated by the Road Accident Fund Act 56 of 1996.

13913 of 2004. 
participation and it adopts a categorical and means-tested approach to social assistance. ${ }^{140}$

The manner in which the South African system is organized is a challenge for persons with disabilities as the focus lies on those who are involved in formal employment.

In terms of the Compensation for Occupational Injuries and Diseases Act $^{142}$ (COIDA) an employee who is injured on duty and suffers a permanent injury resulting in a disability, will be compensated according to the assessment on the percentage of disability sustained.

The South African administration of social-security benefits are affected by several state departments. Owing to the lack of communication between the departments it results in a system that does nothing to encourage a person with a disability or a newly-disabled employee to enter the labour market or to remain in employment. For instance, a disability grant also offers free health benefits to a person with a disability that is essential in disability management. Once employed, the person with a disability, not only loses the income but also the medical care provided by Department of Health. The situation often discourages persons with a disability to engage in the labour market as the cost associated with disability costs is exceptionally high. It also discourages small employers to employ a person with a disability as they cannot afford to provide medical benefits.

\section{LESSONS FROM OTHER JURISDICTIONS}

"It is ability that mattered, not, disability which is a word that I'm not crazy about using"

Best Actress Award 1982 - Marlee Matlin (hearing impaired)

Since South Africa is a young democracy it is imperative to review its developing legislation against international labour law. The South African Constitution compels a court, tribunal or forum, when interpreting the Bill of rights, to consider international law.

\section{Employment equity in Canada}

The South African equality legislation is modelled after the Canadian Employment Equity Act. ${ }^{144}$

Internationally, Canada is recognized as a world leader in welcoming diversity and including all ethnic and racial groups in the nation's social and economic life. ${ }^{145}$ One of the earliest reports on equity was tabled in 1984 by Judge Rosalie Abella who used the term "employment equity" to distinguish

\footnotetext{
140 Jordaan et al Understanding Social Security 24

141 Jordaan et al Understanding Social Security 19.

142 Act 130 of 1993.

$143 \mathrm{~S} 39(1)(\mathrm{b})$.

$144 \mathrm{Http}: / /$ www.hrsdc.gc.ca/eng/lp/lo/lswe/we/review/report/main.shtml Employment Equity Act Review (2001) 5.

145 Employment Equity Act Review 4.
} 
the Canadian initiative from the American affirmative-action programmes which have been associated with quotas. The stated purpose of the Act is:

"to achieve equality in the workplace so that no person shall be denied employment opportunities or benefits from reasons unrelated to ability and, in the fulfilment of that goal, to correct the conditions of disadvantage in employment experienced by woman, Aboriginal peoples, persons with disabilities and members of visible minorities by giving effect to the principles that employment equity means more than treating persons the same way but also requires special measures and the accommodation of differences".

For this reason the four designated groups addressed in equity legislation aimed at women, Aboriginal people, persons with disabilities and visible minorities.

The Employment Equity Act that came into force in October 1996, extended coverage to the federal public service, mandated the Canadian Human Rights Commission to conduct onsite-compliance reviews, and provides for final enforcement of the Act, including by an Employment Equity Review Tribunal, empowered to hear disputes and issue orders. ${ }^{147}$ The Minister of Labour is responsible for advising employers, analysing employers' reports, reporting to Parliament on progress achieved and implementing the Federal Contractors Program. The Federal Contractors Program for employment equity requires enterprises with 100 or more employees with the Federal Government to certify their commitment to implement employment equity initiatives in order to bid on contracts over $\$ 200,000$. The Act requires a committee of the House of Commons to review the legislation to be undertaken every five years.

Canada is one of the few countries, similar to South African, that have one "umbrella" piece of legislation for its four designated groups, while most other industrialized countries address the designated groups under fragmented legislation. ${ }^{149}$

Two other countries that command attention for review are the United States of America (USA) and the United Kingdom (UK) due to the implementation of comprehensive legislation and the successes reflected in employment statistics.

The overall employment rate in the USA for persons with disabilities in the age group 21 to 64 years was 75.1 per cent. This is only slightly below the overall employment rate of 80.5 per cent in the USA.

In the UK the figure is lower with 50 per cent of persons with disabilities of a working age being employed, compared to 80 per cent of non-disabled persons being employed. ${ }^{\text {.5 }}$

146 Purpose of the Canadian Employment Equity Act 19963.

147 Employment Equity Act Review 4.

148 Ibid.

149 Ibid.

150 Van Staden A Strategy for the Employment of Persons with Disabilities Submitted in fulfilment of the requirements for the degree University of Pretoria PhD in Labour Relations Management in the Faculty of Economic and Management Sciences (2011) 91. 


\section{The United States of America}

In the United States of America, a number of laws and programmes protect the vulnerable groups, namely women, individuals who are over 40 years of age, persons with disabilities, war veterans and racial minorities.

Dr Martin Luther King Junior made his "I have a dream" speech on 28 August 1963 which also had an impact on the proposed legislation. His speech was followed by the bombing of a black church in Alabama and the killing of several children. This led to the strengthening of the key provisions of Title VII. The key features of this process included the establishment of the US Equal Employment Opportunity Commission and made Title VII applicable to all employers with more than 25 employees. The bill was sent to the Rules Committee the day before President Kennedy was assassinated and it was signed into law on 2 July 1964. The legislation that followed this was the first major American civil-rights legislation, specifically Title VII of the legislation dealt with prohibition of discrimination in employment. ${ }^{151}$

\section{The Americans with Disabilities Act of 1990}

The Americans with Disability Act (ADA) was the nation's commitment that its sorrowful legacy of oppression, segregation and inequality in dealing with disability would be overturned by the ADA's clear and comprehensive national mandate for the elimination of discrimination against individuals with disabilities in which sweeping protections were provided in employment, public service, public accommodation and services operated by private entities, transportation and telecommunications. "The ADA has been the impetus for revolution in the inclusion, integration and empowerment of Americans with disabilities". ${ }^{152}$

There are similarities in the EEA and the ADA. Both Acts provide detailed information regarding the concept of disability. The Act serves the same purpose of addressing discrimination within the employment setting against people with disabilities. Both highlight the need for reasonable accommodation to address special needs in the workplace. There is, however, a dissimilarity. The ADA does not require affirmative-action plans as the EEA does. However, the ADA has played an important role in creating employment opportunities for people with disabilities in the United States.

The ADA and its various supporting assistance guidelines are easily accessible. These documents have been laid out clearly and they were written in a style which is easily understood. The level of detail, especially in the guidelines, is extensive and easy to understand. Examples are provided to clarify issues. The technical-assistance guidelines especially are voluminous as a result of their comprehensiveness. They are, however, easy to read and to find the information required.

\footnotetext{
151 lbid.

152 Introductory Paper: The Americans with Disabilities Act of 1990, October 2002.
} 
The ADA is further supported by the Disability Discrimination Act of 1995 or the DDA. What is significant in this Act is that the section that refers to employment applies to any organization employing staff, irrespective of how many people are employed.

The employment provisions in the DDA are similar and require an employee to consider the needs of a prospective or current employee, so what is put in place is focused on individual requirements, rather than on developing inclusive and general policies and general good practice. ${ }^{154}$ The DDA is, similar to the ADA, very comprehensive and further enhanced by the Code.

\section{Disability legislation in the United Kingdom (UK)}

In the UK the Disability Discrimination Act, 1995 (DDA) and coupled with the supporting Code of Practice Employment and Occupation issued by the Disability Rights Commission, 2004, provide for protection for persons with a disabilities in the workplace. The Code does not impose any legal obligations. The Disability Rights Commission (DRC) has statutory powers to work towards the elimination of discrimination and to promote the equalization of opportunities for disabled persons. The DDA includes extensive recruitment regulations specifically aimed at favouring disabled applicants. The Act establishes wide-ranging obligations on accommodation and accessibility as well as protection against discrimination. ${ }^{155}$

\section{EMPLOYMENT-EQUITY LEGISLATION IN PRACTICE}

"... the failure of any nation to adopt humane conditions of labour is an obstacle in the way if other nations which desire to improve the conditions in their own countries." Constitution of the ILO

In a public address in November 2006 the previous Minister of Labour, Mr Mdladlana, made much about tightening the noose on employment-equity violators.

It is clear that the country has some of the most comprehensive legislation and policy protection measures of promoting the rights of persons with disabilities in the world.

The key questions remain:

- How effective have the legislation and policy environment been in making real changes to the lives of persons with disabilities?

- Are policies being implemented and acted on, or do they 'evaporate' the closer one gets to grass roots?

153 Http://www.dacymru.com/dwl//nfoDDA.html 3 (accessed 2013-01-07).

154 Ibid.

155 Www.1eeoc.gov/laws/statutes/ada.cfm?renderforprint=1 Americans with Disabilities Act and Regulations, US Department of Justice A Guide to Disability Rights laws, September 2005.

156 Www.skillsportal.co.za/page/human-resources/455759-Minister-to-tighten-noose on employment equity violators: Wed, 22 Nov 2006 15:00 last visited 21 July 2011. 


\section{Evolution of disability as a human-rights and equality issue}

A significent limitation of early United Nations' approaches was an orientation towards treating disability as an individual impairment that was disconnected from the physical and social environment. ${ }^{157}$ The focus was rehabilitation-driven, to enabled the disabled individual to present himself/herself as "whole" as possible so that they could fit into an existing normal environment. There exists no insight that the physical and social environment may be a major disabling factor that may require repair. Therefore the ultimate goal was integrating disabled people into a supposedly "normal life" ${ }^{158}$. Thus the focus has been on the disability rather than the ability.

\section{Efficacy, application and implementation}

While support for the formulation and adoption of policy and legislation have been excellent, policy implementation and enforcement of legislation lagged behind. Two factors that have contributed to the poor implementation of legislation and policies are that the definition and nature of persons with disabilities have not been adequately reviewed and articulated. The policy requirements for disability mainstreaming are not adequately linked to performance management, thereby undermining commitment to implementation. It is also evident that the fact that no separate disability legislation in South Africa exists as in the USA and the UK results in lack of specific sanctions and implementation.

Another factor may be that legislation is not implemented due to a lack of fiscal resources and commitment. Where successful implementation has occurred, it has largely been due to political support and advocacy by the disability sector.

Concerning the implementation of the Employment Equity Act (EEA), and based on information submitted by national departments and provincial administrations for the 797,750 employees employed in the public service, it was found that there are 2,007 disabled employees in the public service. This represents an average of 0.25 per cent $-a$ figure that falls far short of the 2 per cent target that was envisaged for 2005 .

In its report for 2002/03, the Commission for Employment Equity (CEE) reported some improvements in the employment of disabled people by all employers - both Government and the private sector. According to CEE, altogether employers reported a total of 26,539 employees with disabilities in 2002. This represents 1 per cent of all employees included in the 2002 employment-equity reports. ${ }^{160}$

\footnotetext{
157 Dupper and Garbers Equity in the Workplace 185.

158 Ibid.

159 Dube "The Role of Effectiveness of Disability Legislation in South Africa" March 2005

60 Ibid. Disability Knowledge and Research 8.
} 
Out of a total of 26,539 (100 per cent) of employees with disabilities in various occupational categories, 14,045 (52.9 per cent) were African, 3,578 (13.5 per cent) were coloured, 1,138 (4.3 per cent) were Indian and 7,778 (29.3 per cent) were white. ${ }^{161}$

\section{Legislation a barrier to integration?}

\section{Discrimination legislation}

The question bodes that if South African equality jurisprudence has been a forerunner in terms of progressive thrust, why is this not evident in the result?

Ngwena $^{162}$ opines that South African disability jurisprudence is at a nascent stage. Courts have rarely been given the opportunity to adjudicate on disability as a non-discrimination issue. The courts still seems to grabble with the definitional issues as clearly displayed in IMATU v City of Cape Town. ${ }^{163}$

The Constitution and the LRA provide for the regulation of unfair treatment in the workplace via a provision for unfair labour practices. Perhaps the most surprising aspect of our law on equality is that, given the deeply divided nature of our society, there is so little of it. Where are the discrimination cases, the equal-pay suits and harassment litigation?

Similarly, other countries with a less entrenched pattern of discriminatory behaviour are beset with anti-discrimination litigation.

An interesting judgment is Gebhardt and Education Labour Relations Council, ${ }^{164}$ where a review application focused on the difficulties that employers face when confronted with the application of employment-equity targets where applicants for promotion are members of different designated groups.

The applicant suffered from hearing loss and heavy bouts of vertigo when she applied for a promotion post at the Boland College of Education (she had acted in this position for three years) and mentioned her hearing disability on her application form. Although she obtained the highest score on the criteria, nevertheless the candidate with the second highest score was appointed. The appointee was a coloured lady.

The applicant referred the matter as an unfair labour practice as she did not agree that the appointee from a designated group should have been appointed in line with the employment-equity targets and that there was a "under-representation" of coloured females in the workplace.

Steenkamp J, held In this matter the arbitrator did not apply his mind and confirmed that it is the duty of the employer to effectively implement affirmative-action measures for people from designated groups such as

161 Ibid.

162 Dubber and Garbers Equality in the Workplace 183.

163 [52].

164 Unreported 2012 (LC). 
people with disabilities. ${ }^{165}$ This case confirms the position of the applicant with a disability as part of a designated group, deemed to be less important than that of race. Even in this case the employer did not take note of the disability of the employee and did not consider the weight this may carry in the equity plan.

The matter was resubmitted to an arbitrator to consider the unfair labourpractice claim.

It needs consideration to how far the promise of South Africa's equality laws match the reality, and we need to develop a compass to orient legislative, judicial and policy efforts to match the way forward.

\section{Employment legislation}

The employment-legislation aims to set minimum conditions of employment and to regulate health and safety for the protection of employees makes no special provision or distinction for persons with disabilities.

\section{Social security legislation}

The form of assistance provided, combined with the past medical approach to disability issues, places persons with a disability in a disadvantaged position. Being the recipient of social assistance is often seen as a sympathetic handout and not as part of a more comprehensive strategy which is aimed at restoring the dignity of a person with a disability and to reintroduce them into the mainstream of society and economic life. It also creates the mental state that a person is only good enough to receive a handout and not good enough to earn a living. It also results in that the person receiving the handout, give up the challenge to better themselves as they become dependent on the social assistance, without their making a meaningful contribution to their livelihoods. The low representation of persons with disabilities in employment in the labour market may likely be due to the payment of a disability grant. The majority of persons with disabilities have limited education, and when employed it is often in an entrylevel position at a minimum wage. The effort of employment and the associated costs related to employment amongst others, transport, clothing and high disability maintenance costs, such as medication and assistive devices, could easily make it a better financial proposition to rather receive a disability grant than to fight for employment. Social security could thus directly have a negative impact on employment of persons with disabilities.

One of the key issues is that disability issues have been addressed in a piecemeal, fragmented fashion, coupled with a serious lack of reliable information on the nature and prevalence of disability in South Africa, with the lack of interdepartmental liaison and policy formulation.

165 [25]. 


\section{Dispute resolution}

Rights without effective remedies are hollow. The right not to be discriminated against is devalued if there is no means of enforcing this right.

Disputes relating to unfair discrimination issues must be referred to the CCMA for conciliation within six months of the act or omission that allegedly constituted the unfair discrimination. At failure to resolve the dispute a party may refer the matter to the Labour Court for adjudication. ${ }^{166}$ The parties may, however, consent to the arbitration of the dispute by the CCMA.

A dispute about an alleged unfair dismissal on discriminatory grounds is typified as an automatic unfair dismissal. The same dispute-resolution path is afforded. However, if a bargaining council exists for a specific industry that has jurisdiction the matter needs to be referred to the Council for conciliation.

Again the reason for dismissal is important. If an employee is dismissed on the basis of incapacity the dismissal will be fair, if a fair reason exists and a fair procedure was followed. A dismissal based on disability may be automatically unfair, giving the employer no defence and the judge no direction - except that the dismissal may be fair if the reason is based on an inherent requirement of the job and the dismissal is both substantively and procedurally fair.

According to the statistical information available from the CCMA very few disputes have been referred in terms of the EEA. Perhaps these have generally being dealt with as unfair labour practices and not as discriminatory referrals.

It is a further a contention that the dispute process further marginalizes the already marginalized group as the process of conciliation often results in an unresolved outcome. The individual affected by this outcome seldom has the resources to refer the matter to Labour Court.

The Employment Equity Amendment Act, 2014, makes provision in section 10 for the amendment and these disputes may now under specific provisions be referred for arbitration to the CCMA.

\section{The definition of persons with disabilities}

One of the first challenges posed is the definition of Persons with Disability as set out in the EEA. The broad definition leaves confusion when incapacity and disability are discussed in the interchangeable manner even as referred to in the Code on Dismissal as contained in Chapter $8 .{ }^{168}$

Reviewing the definition in international legislation and ILO documentation it seems to be even more inclusive as serious illnesses, such as HIV, is also included in this definition, which then proportions a larger group in society.

\footnotetext{
EEA s 10(6)(a).

67 S 10(6)(b).

168 As contained in the LRA.
} 
The definitions of "accessibility" and "reasonable accommodation" are vague and are seen by employers as a further onerous barrier to employee persons with disabilities. It is also common cause that laws governing physical accessibility to buildings and venues are not enforced.

Strict enforcement of the National Building Regulations must be adhered to; failure to comply should be regulated by substantial fines and/or of nonapproval of plans.

It is further viewed that the terms "impairment", "substantially", "long-term" and "recurring" were indicated as being unclear and perhaps the word "substantially" should be omitted. ${ }^{169}$

It was advised in research by Van Staden ${ }^{170}$ that all disabilities should not be lumped together. The definition should provide for levels of disability within the various categories. A rating system similar to the BBBEE scorecard was suggested to identify the disability types. ${ }^{171}$

In the research thesis 38 respondents with disabilities recommended that the definition be amended to: "Persons who have a long-term or recurring physical or mental impairment that substantially limits their prospects of entry into performance and/or advancement in employment." 172

\section{The effect of labour legislation in integration and promotion}

Although, as previously conferred, the comprehensive discrimination legislation still seems to fail to draw the attention of employers.

A separate Act similar to the proposed services bill will have the same effect as for instance the ADA.

A separate Act and guidelines to demystify the issues addressing the employment, including reasonable accommodation and environmental accessibility, of persons with disabilities are required.

The focus seems to be more on legislation and policy making to align with the Constitution and International standards in order to impress, than to have concern for the implementation and the removal of barriers in the employment of persons with disabilities.

There seems to be a lack of defined targets set for the employment of persons with disability, and the compliance is not measured. Black people are seen to be historically disadvantaged and the matter seems to be politicized to a great extent. Persons with disabilities have an ongoing struggle with stereotyping and discrimination and should be regarded as "continuously" disadvantaged. The broad target set at two per cent is not enforced and no sanctions are associated with failure to achieve the target.

\footnotetext{
A Strategy for the Employment of Persons with Disabilities 237.

Ibid.

lbid.
}

172 Ibid. 
Specific targets should be set for specific industries such as in the FASSET sector, which are very proactive in their approach. The focus should be shifted to the person with a disability instead of the other designated groups, specific industries will have specific skills needs that could be presented as a career path to persons with disabilities, with the financial support provided in the form of a bursary to suitable candidates.

The targets should be enforced with penalties where applicable. Currently the new amendments to the EEA, Act propose substantial penalties that are mainly focused on designated employers that fail to comply with EEA legislation. This compliancy mainly focuses on people of colour and women. The lack of compliance needs to be addressed by properly trained civil servants to ensure implementation and compliancy.

\section{Human-resource management to include disability management}

Senior management in public sector as well as private sector needs to be trained and desensitized to effectively manage disability issues.

In addition to training managers on the management of disability it should be part of the managers' key performance areas in performance agreements. This will ensure compliance and commitment in implementing disability legislation. Knowledge on disability and its reasonable accommodation is a highly specialized field, and this should be included in the rehabilitation of the person who has recently being disabled, to encourage such a person with a disability to remain in the labour market.

\section{Skills development}

The advantages as offered in the Skills Development Act to companies should be utilized and promoted. A general lack of knowledge exists in regard to any benefits that may be applicable when an employer offers employment or a learnership to a person with a disability. The Department of Higher Education and SARS, and even the Department of Labour, which are the custodians of employment-equity-reporting should make a combined effort to make the aforementioned information more accessible and available.

The financial benefits available from the Skills Development Act and SARS should be more widely promoted and made more accessible for small businesses.

\section{CONCLUSION}

The fact that the South African legislative framework prohibits discrimination against persons with disabilities, but the key-role players who should implement it, are not aware thereof fail to implement it and nullify the value of the said legislation. The call is for a separate set of legislation that is strictly enforced and that the existing employment legislation be adapted to address the specific needs of employment of persons with disabilities. 
The Constitution, EEA, the Code and the TAG are all very useful but are not sufficient to enforce and to effectively integrate persons with disabilities into the labour market.

These legislative and policy instruments are hardly ever used to assist with disability management in the workplace. An awareness programme aimed at business should be created by the custodians of this legislation.

The institutional efficiency of State is not adequate to ensure the full implementation of legislation, policies and strategies between the different departments responsible for different areas in regard to dealing with disabled people, State failed in its responsibility and implementing promises to people with disabilities as set out in policy documents, legislation and international instruments such as the ICRPD.

This failed responsibility manifests within Government as an employer and which through employment-equity reporting should monitor employers' progress made in this regard.

The leadership of South Africa must visibly demonstrate their commitment to persons with disabilities. Political, Government and business leaders should set the direction and the pace in transforming the present worrying situation of persons with disabilities in South Africa.

This again confirms that labour as a social phenomenon is not only concerned with workplace-related issues but also all aspects encompassing the whole of the socio-political and economic scenario. 